\title{
The Higher Order Thinking Skills of Students on Visayan Poems
}

\author{
Armand James A. Vallejo \\ Tagum College, University of Mindanao, Philippines
}

Copyright $(2019$ by authors, all rights reserved. Authors agree that this article remains permanently open access under the terms of the Creative Commons Attribution License 4.0 International License

\begin{abstract}
Dissecting the understanding of the students on Visayan poems prevails appreciations. This intensifies the level of comprehension and interpretation towards poems. This explanatory sequential research dissected the higher order thinking skills of English major students. This project focused on the identification and understanding of the students' weakness in analyzing, comprehending, and understanding the Visayan poems. The researcher crafted the researcher-made test and identified the level of the higher order thinking skills of the students. Both generation and explanation skills of the students were found to be on satisfactory levels while selection skill is considered as the major problem in which students had a difficulty in answering the test on Visayan poems. Using this finding, the researcher conducted a semi-structured interview for further investigation. In the interview, it was found that students have difficulty in answering the test questions. This difficulty specifically includes: distinguishing the open-ended type of test, such as uncertainty in identifying the meaning per stanza like ability of categorizing the connotative meaning, and ability of recognizing the denotative meaning; identifying the meaning of the symbols; understanding the implication of the poem; identifying the meaning thru figurative language; translating the Visayan words and phrases; and using appropriate words or diction. Given this result, an extensive review of the curriculum is much needed to address the emerging problem.
\end{abstract}

Keywords Higher Order Thinking Skills, Sex, Poem, Visayan, Philippines

\section{Introduction}

Dissecting literary text provides a wide range of interpretation. Its interpretation usually depends on how it is internalized. The essence of this claim is the appreciation of the poems. Appreciation happens when one can understand the text - connotatively and denotatively. Moreover, knowing the different meanings of literary pieces can reflect students' understanding. The involvement of higher order thinking skills showcases the appreciation, evaluation, and understanding of a text to unlock the doubtful mind.

Higher Order Thinking skills play a vital role in the process of transferring knowledge. It is then a manifestation that students should gauge and enhance self-confidence in dealing with individuals. It is a sad fact that there are students who do not do well in understanding its own mother tongue. Lenz (2008) argued that students in Malaysia have no courage to communicate well because they lack confidence.

The consequences of misunderstanding the literary piece would lead the individuals to choose the wrong concept on understanding. The impact of writing a poem shows a lot of interpretation. Different point of views is revealed by different critics. Thus, Estrecho and Fernandez (2011) discovered that upon writing a poem, there is an idea that there came no possible reliable source of information for the topic. It was believed that individuals nowadays are not fond of reading literary text; instead, they are more spatial and like watching in the television, or surfing the internet.

Further, poems are not written because of the intention to arouse the emotion of the individual; instead, it intends to develop appreciation the individuals' work based on the experiences. Also, it allows people to append their feelings towards the literary text (Illouz, 2014).

The conceptualization of improving oneself towards understanding the literary piece materializes through intertextualization. This addresses the critical concern of method used in analyzing the text (Ellis, Adams \& Bochner, 2011; Struthers, 2014). Moreover, Crawley (2014) argued that it contributes to our emancipation from the creative limitations of validity, reliability, and generalization, freeing us to examine cultural phenomena for a perspective rooted in our own lived experience and allows us to claim the 'scientific-ness' of our innate inner-lives

In the Philippine context, Remote (2017) posits that in understanding the literary text, realism, humor, or the unusual are all ingredients in integrating a Filipino literary piece to have a better understanding of the concept. Meanwhile, in assessing student's higher order thinking skill, there is a need of special attention for a language teacher. Allowing students to interpret, provide meaning, 
and comprehending the different literary text would lead them to become holistic individuals. Evidently, the result of the conducted study by the Department of Teacher Education of University of Mindanao - Tagum College to its graduating students, in the specialized area, English major students performed poorly in the standardized test. The standardized test follows the principle of cognitive domain wherein, it allows the gauging of the higher order thinking skills of the students. As a result, 5.41 percent of the English major students were not able to graduate and earn their degree that year.

The study aimed to look into the higher order thinking skills and problems in interpreting the Visayan poems.

\subsection{Higher Order Thinking Skills}

Dick, Carey, and Carey (2014) argued that solving, understanding, and analyzing a mental concept are among the higher cognitive domains. These skills enable students to think critically and evaluate an argument, and develop and support their claim (Bassham, Irwin, Nardone, \& Wallace, 2012). Meanwhile, it was noted in Malaysia that students should develop their ways of solving a critical problem for them to be prepared for their career (Ministry of Education (MOE), 2013; 2015). It was added that employers are looking for applicants who are creative and innovative. Higher academic institutions are working doubly hard to develop graduates for the job market who are critical and innovative thinkers, problem solvers and holistic, well-balanced future professionals.

Test and examination generally classify the quality of graduates. This is the reason why many courses are now professionalized. Moreover, students' academic performance depends on the validity of the test being used. Allowing students to become more multifaceted individuals, strong foundation of knowledge must be developed. This is how they will think comprehensively. Thus, classroom teachers recognize the importance of having students develop higher order thinking skills (HOTS) yet often do not assess their students' progress. Several performance-based models are available to assist them in teaching and assessing these skills. Comprehensive statewide assessment of higher order skills is feasible but would be expensive (King, Goodson \& Rohani, 2010).

In this manner, assessing critical thinking is a complex mental process involving paying attention to details, selecting relevant information, analysing carefully and skeptically, making judgments, and metacognitive thinking such as reflection and higher-order planning (Cottrell, 2005). It is an essential skill for both academic achievement and for dealing with various real-life problems. Critical thinking, as a generic thinking skill, is emphasized in a variety of content areas of curriculum planning documents across cultures. Critical-thinking curriculum is relatively more difficult to be implemented in Asian classrooms because the teachers and students are more accustomed to the passive, transmissive, and knowledge-based model of learning; thus, more clear practice guidelines and more transitional time are needed for Asian learners to practise and acquire this essential skill (Vandermensbrugghe, 2004).

Furthermore, creative thinking is the ability to look at problems and situations in new ways, be able to generate new ideas and provide original, elaborative, and appropriate solutions. Creative-thinking skill, as an essential ability for success, has been emphasized in the curriculum across cultures (for example, Curriculum Development Council 2007; British Columbia's Ministry of Education 2010). Instructional and learning models following the constructivist and student-centred approaches are more likely to help learners acquire and practise creative thinking. For example, in an e-learning setting (Sultan, Woods \& Koo 2011), constructivist environments were found to reinforce creative thinking in addition to the knowledge acquisition. Therefore, it is more difficult to implement in examination-driven and teacher-centered educational cultures.

In consonance, metacognition can be considered as the knowledge, awareness and control of one's own thinking and learning processes. This includes knowledge of cognition and regulation of cognition. The abilities of self-regulation and metacognition are emphasized in the curriculum guidelines in both Western and Asian educational systems (Curriculum Development Council, 2007; British Columbia's Ministry of Education, 2010).

However, Seif (2012) stated that there are reading materials, which significantly lack quality to enhance the HOTS of the students. Thus, modifying the reading exercises by providing them with more enrichment material that includes HOTS is highly recommended. English language supervisors are also recommended to hold more workshops to train English language teachers in how to enhance such skills in students' mentalities.

\subsection{Poetry Interpretation}

Poetry, which springs from one's feelings, is provoked through thinking, and is expressed through writing. It is a sad reality when one interprets the poem inaccurately. Accordingly, Sylvan (2008) affirmed that upon interpreting the poem, there must have a focus on the other aspects such as the meaning of other literary devices shown by the characters and their gestures. This simply means that poem is a symbolic language of figures whose elements can be interpreted openly towards new meaning, levels, and dimension (Alghadeer, 2008).

Further, Siswantoro, Ahmad, and Sulaiman (2002) asserted that poems are means of communication. Thus, it is a language, which is expressed with deep emotion and enjoyment through one's environment or imagination. Poem uses language that has a direct and straightforward interpretation. In this instance, figurative language has been applied.

Figurative language is one of the factors affecting the interpretation of the poem. It gives beauty and life to this work of art. Aside from that, it gives non-literal meaning. It 
is used by some authors in writing to gain strength and brightness in presenting their work. In doing so, it reveals the heart and the character of the writer (McGlone \& Glucksberg, 2001).

There are two common figurative languages used in writing a poem. These are metaphor and simile. There are three components of metaphor focusing on single words that are, deviation from literal language, to produce a change of meaning based on similarities on things. Metaphor is an implied simile (Weiss, 2006). It is a literal expression usage denoting one kind of things without asserting any comparison. Paul (2015) added that metaphor shapes new being to reality, brought by carefully-thought actions of the critical mind. This gives readers a special attention to the primary meaning of the words, which are used metaphorically.

On the other hand, simile is an easy way to compare two things. It uses some connectives, usually like, as, an, than, and sometimes verbs which are congruent (Kennedy, 2009). There are two types of simile namely explicit and implicit. Directly, explicit simile happens when two things are compared. Meanwhile, implicit simile is used when the involvement of the readers occurs. Meaning to say, the readers infer on what is being compared.

Metaphor and simile are both used upon comparing two things. The conceptual metaphor theory regarded similes and metaphors, and the usage. This means that although these two are similar but there is no significantly distinguishing meaning (Kim, 2003).

\subsection{Differentiated Test}

To demonstrate students' growth and performance, an effective assessment program uses multiple testing strategies. In addition, it should be closely correlated to the stated program goals. Projects in which students create multimedia presentations, web pages, artwork or songs may be evaluated differently than traditional written, typed, or even word-processed papers. Assessment strategies can include performance tasks, teacher observations, personal communications, standardized testing, and student and teacher developed evaluation rubrics, and others (Gabuyo, 2012).

Thus, the term standardized tests is often heard along with high-stakes. Standardized tests are administered, scored, and interpreted in a consistent way, so that the performances of large groups of students can be compared. They are not high-stakes in themselves, but they are often used for high-stakes purposes such as determining which students will pass or graduate, which teachers are fired or given raises, and which schools are reorganized or given more funding. Heard less frequently are discussions of the effects of high-stakes standardized tests on students' learning. It was found that these effects include changing the nature of teaching, narrowing the curriculum, and limiting students' learning. English language Arts (ELA) teachers and their students feel these effects with special force because literacy is central in most standardized tests
(National Council of Teacher of English, 2014).

Surprisingly, English language learners are currently the fastest-growing population who represent another group whose learning is limited by standardized tests. The results of standardized tests usually determine whether students will receive the designation English language learner and the support services that go with it. Unfortunately, the tests English language learners take are not always valid measures of their ability, and their opportunities to learn are diminished as a result. Instead of receiving the support they need, students are assigned to classes where their learning is hampered because they cannot understand the language being used (Nelson, 2013).

Standardized tests are powerful and often have negative effects on student learning, but their negative effects can be reduced by measures. The multiple assessments, standardized test on its validity, reliability, and accommodations are among concern of the test. This caters the understanding of the individuals (Wiggan, 2014).

Furthermore, the term assessment for learning (AFL) has been used interchangeably with formative assessment. It was argued by Lam (2014) that the formative function of assessment is to improve students' learning. Formative assessment is normally informal, continuous, interactive, small-scale and classroom-based. Its task types could be any learning tasks such as self- and peer-assessment. The key promise of AFL is integrating teaching, learning, and assessment. In this view, learning is a goal in its own right, and assessment is a means of achieving the goal. Furthermore, this assessment is the process of finding evidence in determining where learners are in their learning, where they need to go and how best to get there (William, 2011). Lastly, assessment for learning is part of everyday practice by students, teachers and peers who seek, reflect upon and respond to information from dialogue, demonstration and observation in ways that enhance ongoing learning (Klenowski, 2009).

Within an English language teaching (ELT) context, Murphey (1995) conducted a study where he encouraged students to create their own word lists, grammatical concepts, and content that they thought were important. The lists from students were synthesized and all the test items were based on that list. The results of the study showed that students involved in the process of test creation were intrinsically more motivated and they achieved higher scores in the test. Finally, in a more recent ELT-related study, Ashtiani and Babaii (2007) probed the effect of EFL students' cooperative test construction on their grammatical knowledge as well as their attitudes toward such tests for a period of sixteen weeks. The students of the experimental group were asked to construct test questions. After discussing their constructed items in pairs and then in groups of four, the teacher checked and corrected the students' constructed tests and modified them slightly. At the end of the term, the students in the experimental group were asked to take part in the process of constructing the final test cooperatively. The findings 
revealed that the grammatical knowledge of the students involved in the experiment was significantly better than that of the students in the control group. Furthermore, administering a Likert-type scale questionnaire to investigate the students' views regarding this type of assessment revealed that the students' attitude to cooperative test construction was positive.

Considering the impact of student-generated tests on their learning in different fields of education and second language learning contexts, the effects of this assessment method on EFL learners are not so clear. In other EFL contexts, traditional methods of language testing are dominantly used in language teaching and assessment fields. From elementary schools to universities, language learners take different language tests at the end of the course to demonstrate their abilities and be evaluated based on their test scores. In recent years, however, some innovative language teachers have applied new ways of assessment in their language classes, but such practices are still in their infancy. Moreover, the concept of such assessment for learning has not gained its deserved reputation (Zarghami \& Baleghizadeh, 2014).

In educational assessments, reliability, validity, and fairness are the three major indicators of quality (Huang, 2008; 2009; 2011; 2012). A high-quality assessment, therefore, should be reliable, valid, and fair (Popham, 2008; 2011). In addition, assessments need to be reliable and valid in order to be fair. Fairness has been the priority in educational assessments during the past few decades. Educational organizations, institutions, and individual professionals should make assessments as fair as possible for test takers of different races, genders, and ethnic backgrounds. Thus, satisfying the students' academic competence depends on how assessment is crafted. The assessment of learning, assessment for learning, and assessment as learning should be observed.

This study is anchored on the theory of higher order thinking skills by King et al., (2010). It was stated that students develop their higher order thinking skills in a complex manner to resolve any academic problem. With this idea, the concept that will allow the students to enhance their skills should be tested according to selection, which includes multiple-choice, matching, and rank-order items; generation, which includes short answer and essay; and explanation which involves giving reasons for the selection or generation responses as proposed.

\section{Method}

This study used mixed method design. It started with the collection and analysis of quantitative data. This first phase is followed by the subsequent collection and analysis of qualitative data. The second qualitative phase of the study is designed so that it can connect and validate the results of the quantitative phase. Since this design started quantitatively, investigators typically place greater emphasis on the quantitative methods than the qualitative methods (Ivankova, Creswell, \& Stick, 2006).

The participants were English major students, which suit the study thus, simple random sampling was used. Every individual in the sampling frame (i.e., desired population) has an equal and independent chance of being chosen for the study (Onwuegbuzie \& Collins, 2007). The size of the sample should be informed primarily by the research objective, research made questions, and subsequently, the research design (Creswell, 1998 as cited by Mason, 2010; Morse, 1994; Lasch, Marquis, Vigneux, et al. 2010; Onwuegbuzie, Leech, \& Collins, 2010; Babbi, 2001). Also, triangulation in the study was set (Denzin, 1978; Zohrabi, 2013; Richards \& Schmidt, 2002).

The teacher-made test questionnaire was generated from the Visayan poems, such as Balaki Ko 'Day Samtang Gasakay Ta'g Habalhabal by Adonis G. Durado, Usa Ka Gabiing Way Sud-An Ug Way Bituon Ug Sa Akong Nasabtan Ang Angay Basulon Mao Ang Kulafung Gilaklak Ni Papa by Adonis Durado, and Binangkal Penelope by Corazon Almerino, which are all included in the literary collection in the curriculum specifically during the first semester of the school year. The said literary pieces were written in Visaya - a widely spoken dialect in the Philippines particularly in the inlands of Visayas and Mindanao. The said Visayan poems are discussed before the third assessment in the classroom discussion. Each question was based on the topics about Visayan literary piece.

In interpreting the HOTS of the participants, statistical tools such as mean and standard deviation were used. Furthermore, the rating scale was adopted in interpreting the scores and its verbal equivalent to describe the level of students' performance (Blaxter, Gray \& Johnson, et al., 2006). This is to measure its dependability and accuracy. Rating scale served as the main source of revealing the interpretation of the data gathered. Also, it investigates the level of competence of the students allowing for go beyond identifying of the problems.

\section{Results and Discussions}

Based on the result, the level of the higher order thinking skills of English major students is 15.69 with the verbal description of satisfactory. Among the indicators, generation is revealed as the weakness of the students in interpreting the questions and understanding the Visayan poems. It was further revealed that students encountered problems in the open-ended type of test, which involves (1) identifying the meaning per stanza such as the connotative and denotative meaning, (2) meaning of the symbols found in the poems and (3) the implication of the poems to the readers. Meanwhile, the identified problems in distinguishing the answers in a closed-ended type of test were (1) the use of figure of speech, (2) translation of the Visayan words and phrases, and (3) diction.

Level of Higher Order Thinking Skills of College

Students in Understanding Visayan Poems 
Table 1. Level of Higher Order Thinking Skills

\begin{tabular}{|c|c|c|c|c|}
\hline & \multicolumn{4}{|c|}{ Higher Order Thinking Skills } \\
\hline Descriptive Statistics & Selection & Generation & Explanation & Total Average \\
\hline Mean Score & 17.78 & 10.76 & 18.51 & 15.69 \\
\hline Standard Deviation & 3.01 & 4.24 & 7.68 & 3.79 \\
\hline Level of HOTS (Mean) & Satisfactory & Poor & Satisfactory & Satisfactory \\
\hline $95 \%$ Confidence Interval & $17.07-18.49$ & $9.77-11.76$ & $16.71-20.32$ & $14.80-16.58$ \\
\hline Level of HOTS (95\% C.I.) & $\begin{array}{c}\text { Satisfactory - } \\
\text { Satisfactory }\end{array}$ & Poor - Poor & $\begin{array}{c}\text { Satisfactory - Very } \\
\text { Satisfactory }\end{array}$ & $\begin{array}{c}\text { Satisfactory }- \\
\text { Satisfactory }\end{array}$ \\
\hline
\end{tabular}

Table 1 presents the results of the analysis on the higher order thinking skills of English major students in understanding Visayan poems. There are three indicators that measure the level of HOTS namely selection, generation, and explanation. Table 1 presents the data.

As seen on the table, the highest mean score among the three higher order thinking skills is Explanation with a mean of 18.51 which is equivalent to a verbal description of satisfactory. This means that the students have good higher order thinking skills. This implies that students may have a difficulty in expressing themselves through interpreting the Visayan poems. As it describes, there is a manifestation that students are just simply expressing their uncertainties towards the literary piece.

This is in line with the principle of Seif (2010) who believed that utilization of the reading materials should be maximized by the students. Thus, the taxonomy of educational objectives were proposed by Anderson et al (2001) who pointed out that to measure the cognitive domain of students, the level of understanding must be identified to assess the students' learning needs.

Furthermore, the indicator, which got the second highest mean is the selection which has a mean of 17.78 verbally described as satisfactory. This means that the students have a good higher order thinking skills. This simply implies that there is still a need to develop and enhance students' ability of recognizing the appropriate interpretation and understanding the context of Visayan poem.

This is in line with the precept of King et al. (2010) that students' academic performance depends on the validity of the test being used. This will allow the students to become more multifaceted individuals, comprehensive thinkers, and knowledgeable graduates. Thus, the theory of Freud (1912) affirmed that students have an ability to acquire the knowledge unconsciously.

Lastly, among the three indicators, generation is found to get the lowest mean of 10.76, which is interpreted to be poor. This means that the students have deficiency in higher order thinking skills. This implies that the English major students struggle in understanding Visayan poems.

This is in accordance with the concept of the British Columbia's Ministry of Education (2010) which emphasized that students must be acquainted with their metacognition particularly their knowledge, awareness, and control of their thinking and learning process. Students should constantly develop their self-regulation and metacognition. Further, King et al. (2010) strongly affirmed that students must engage in activities that hone their higher order thinking skills to resolve the creative academic problem.

\section{Problems Encountered by English Major Students on Generation Skills}

\subsection{Difficulty in Distinguishing the Open-ended Type of Test}

Different perspectives matter on a certain problem. Consensus unifies idea to create solution. In academic context, students want assurance on their answers especially when a standard is set. Their concern is whether they answered the questions comprehensively. However, because of the individual differences, there is no guarantee that all of the students would answer in the same possible way. This leads to a confusion about how and what the possible answers are to a specific question. From that, I found that students have difficulty in giving their answers. Based on their test responses, their answers seem to be opinionated. Since it is opinionated, they arrived at providing their own perspective based on the situation. A line coming from the poem "Quereda" which states that "One room, a brilliant question mark of light..." is an example, which makes the students find it difficult to interpret. This was reiterated during the FGD.

...mao to naglisud ko ug unsaon pag answer mao to akoa nalang gi answer nako sa paghatag ug akoang opinion (R6, L7)

The result of the study negated the principle of Emanovský and Stepankova (2012) which stated that students should create and form their own answers. Moreover, it was emphasized that students need extra effort in answering the test for it is time consuming and subjective. Further, students may find it difficult to understand and arrive at an exact answer. 


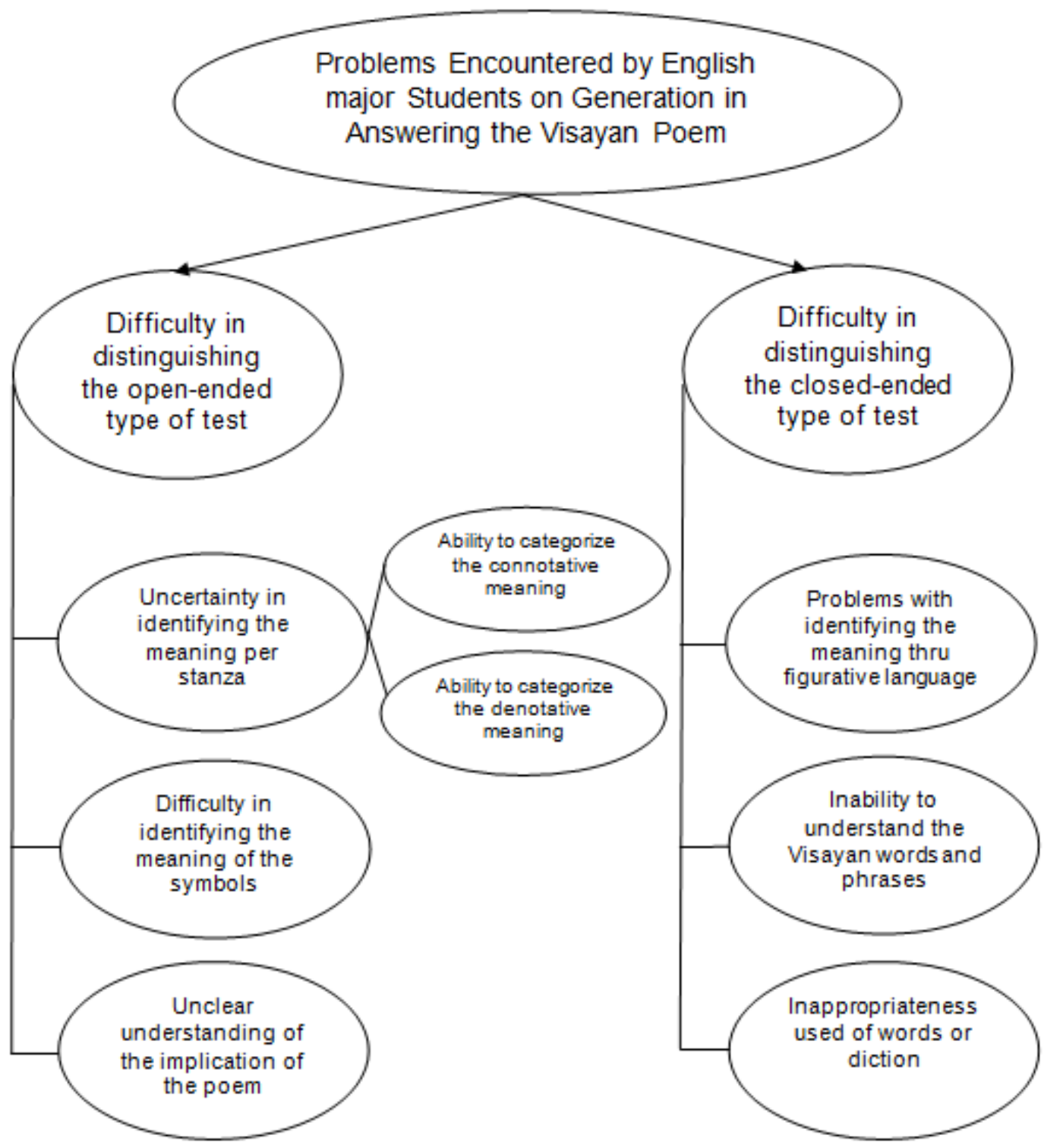

Figure 1. Themes Showing the Problems Encountered by English major Students on Generation Skills

Uncertainty in identifying the meaning per stanza. It is essential for any student to know the hidden meaning of a poem. This helps organize the idea leading to a better understanding. Utilizing this properly can help improve students' thinking skills necessary for optimum learning. Meanwhile, the findings reveal that students' curiosity in dealing with the Visayan poem cause them to fall into the pit hole like the line "Mipungpong sa imong buhok". The curiosity is aroused when positioning them in understanding the meaning, since the poems have double meanings and are too structured. Visayan poems also offer symbolisms and mysteries. This means critical analysis must be executed during literary explorations. Students verbalized these needs during the focus group discussion as stated below:

kailangan sya $n g$ deep analysis ug info kay wala ko kabalo na double meaning jud sya mam, sa akung nasabtan mam bastos siya mam, tungod sa word na " $\mathrm{gi}$ ibut ni mama ang ..." murag nay ga sex na nahitabo jud sa ilaha mam $(R 8, L 1)$

Deep analysis on the Visayan poems is vital for it to give colors in understanding its meaning. The structures of the poems are too vulgar and enticing because it has a double meaning. One-sided interpretation leads to a misinterpretation. With this, unveiling the reality makes everyone free from their own. It is right to get curious on what specific concern will be addressed.

Talking about situation, Hirsch (2007) disagreed the proposition that in analyzing the poem, it needs an effort. It was believed that upon engaging oneself into poetry, identifying the meaning is a less concern for it is part of the attitude and curiosity. Further, in reading poetry, the goal is to formulate question, which has more than one meaning. In addition, it was addressed that upon reading poetry, assumptions are always presented such as readers should 
understand the text in their very first encounter. Poetry may have one hidden meaning that readers must uncover.

Ability to caregorize the connotative meaning. Deeper meaning needs a deeper understanding. The matter of distinguishing the meaning of the Visayan poem reveals that it can have more meanings once appreciated. Since the author uses a language that is playful, English major students encountered difficulty in associating their arguments in the test. They had different speculations and interpretations on the Visayan poems. This was argued by the English major students during the discussion.

padulong na magabie mao jud to pagsabot nako sa ni sid-ok ang bulan mam (R3, L7).

Understanding the situation in the literary piece provide different views. This view shows more than one meaning because of its implication. The implication is categorized according to the presentation of the literary piece. As such, providing an assumption is evident.

Knowing the problem's origin is critical in understanding its meaning. Analyzing its connotative meaning brings uncertainties. This has to be clarified based on its structure. Exploring its unpredictable scenario, it was inferred that something has transpired in the situation when they read the poem. Khatib (2011) affirmed that upon comprehending the poem, students will get different skills and personal benefits such as authenticity, motivation, cultural and intercultural awareness, intensive and extensive reading practice, sociolinguistics and pragmatic knowledge, grammar and vocabulary knowledge, emotional intelligence and critical thinking. Meanwhile, Septiana (2013) argued that connotative meaning is unstable. It varies in the perception of the individuals particularly the language use, culture, and historical background.

Ability to recognize the denotative meaning. The inability to recognize the meaning makes students dumb. Different answers may arise if the question is taken literally. However, it is evident. It was found that for students, it is difficult to distinguish the situations in poetry especially when it tackles erotic issues. In addition, uncertainties were presented lead to literal comprehension and answer. This was shared by the students.

pareha ra sa ilaha mam na nag expect siya na nay mahitabo sa ilaha mam, then ang problem nako kay lisod siya eh criticize and dili pud siya natural na scenario pag makit an sa anak na nag inato ra ang mama, bali murag gi literal ra nako siya pag sabot nako mam. (R8, L4)

Identifying the denotative meaning in the literary piece shows oneness of interpretation. Though its understanding is varied, there is no guarantee that a poem is basically dealing with literal meaning. Denotation interpretation is understanding its literal meaning. However, because poetry has different characteristics, expectation towards particular scenario is always present, and analysis may prove to be difficult.

Basic interpretation begins with a literal understanding. It serves as springboard of one's comprehension. By that, the meaningful appreciation of Visayan poems makes one an effective reader. In addition, literal meaning is assumed to be conventionalized, that is, it does not take any special interpretation effort to arrive at it (Borjesson, 2011). Furthermore, Septiana (2013) confirmed that sometimes, components of poetry meanings are not mentioned. This is a manifestation that word is void in any emotional or subjective over tones when examining other words.

Difficulty in identifying the meaning of the symbols. Symbols in the literary pieces play a vital role. It gives color to the readers' imagination because it allows them to think critically. Thus, study revealed that students fail to understand the existence of symbolism since most of them find it hard to get its meaning in the poem. As shared by the students, they have confusions and expectations towards every symbol found in the Visayan poem.

for me same rapud mam kay libug sya pangitaon pud jud mam ang 3rd stanza kadtung nay dugo (R5, L2).

The difficulty in identifying the object in the text has become a problem in this study since not all symbols are interpreted literally. The confusion appears when a literary object becomes a symbol.

Indeed, symbols are dealt with different domains of human's life. It forms the basis of literature and has a direct relation with poetry. Symbols are used more in epic poems, allegorical and agnostic poems. Shamisa (2004) classified symbols into two types: arbitrary symbols and personal symbols. Arbitrary symbols are those common and familiar ones that the reader can readily recognize, for example, spring is a symbol of youth and freshness. Personal symbols are those fresh and new ones, which the writer or the poet creates solely for a certain piece. Contrary to arbitrary symbols, their recognition and meaning can be difficult for the reader.

Unclear of understanding the implication of the poem. When one cannot figure out the meaning of the poem, so is its implication. This is a sad reality since the real essence of the poem is to know its implication. Moreover, scrutinizing the responses of the students, I found that they have different views and understanding on the erotic themes of the literary pieces.

sa pagsabot nako ma'am kanang ready najud siya unsay mahitabo kay nag underwear raman gud to iyang bana mam basin naay sex mahitabo ug ang implication ani maam kay ang poem naga emphasize siya ug erotic. ( $R 2$, L6)

Understanding the Visayan poem revealed that unclear and unreadiness of the individual to comprehend depends on how it is presented. Variety of understanding on sex-themed Visayan poem encourages own personal understanding leading to unclear interpretation.

Rahman (2009) believed that since sex as a theme in a 
poem can be used as a weapon: (1) a device for insulting people, and (2) a means of embarrassing them. However, the emerging interpretation is crucial because this usage is based on the assumptions and values of feudal society in which the crude use of power is a reality of life.

\subsection{Difficulty in Distinguishing the Closed-ended Type of Test}

Students find it difficult to look for answers in closed-ended test. They make it sure that their answers are certainly correct. Since the closed-ended type of test needs a very specific answer, still students need an assurance of their answers. However, to do this, they had to understand and interpret the questions first before arriving at their answer. This was shared by them in the focus group discussion:

regarding sa question number 4 dili jud kayo siya answeran mam, however na kanang pag interpret namo sa amoa answer wala mi kabalo kung unsa amoa eh interpretation about ato (R3, L1).

Close-ended questions provide misinterpretations because of the uncertainty in giving one's own understanding towards the text. Their own perception is questioned as what really are the meanings of the questions. This leads to a direct answer.

These findings are in consonance to the study of Emanovský and Štěpánková (2012) which stated that the closed-ended type of test provides a direct answer to a given question. Answers are mostly a single word or phrase. Yet, it is divided into dichotomic with choice of answers, assignments, and ordering.

Problems in identifying the meaning thru figurative language. Imagination makes an individual more critically-creative. It expresses more than the expression of one's idea. In creative writing aspect, I found that people are bound to express our emotion in a different way. It could be dull or strong with full of happy emotions. This allows the readers of the poem to inculcate that they need to be imaginative to get the significance of the poem through imaginative language. This was declared by the participants in the focus group discussion:

Okay ra siya para sa akoa mam dali ra siya masabtan pero pag abot lng diria sa lahi ma'am kay ang pag interpret japon kay lahi iyang bana murag gi dungagan pareha sa bloodshupshup, so meaning nako ana mam wala sila nag sex $(R 4, L 1)$.

para sa akoa mam ang mga words naa syay mga metaphor then about sa sexual then sa kadtong naa siyay kutsilyo, murag exaggeration pud kayo siya kung eh translate mam murag nay sexual jud na nahitabo sa situation. $(R 9$, L1)

The problem with the figurative language is its usefulness and effectiveness in conveying the message. The curiosity of the readers leads to misterpretation because of its impact. There is no direct understanding on the part of the readers since the poems are sexually themed.

However, McGlone and Glucksberg (2001) strongly believed that figurative language plays a big role in understanding the concept of the poem. Significantly, it gives beauty to the work and provides non-literal meaning. It was used by the authors to gain strength and brightness in presenting the work since it is a representation of the heart and the character of the writer.

Inability to understand the Visayan words and phrases. "Nagmirida na ang kagabhion, naghikog ang iro sa kaugalingon niyang paghot" is an example that students have an inability to understand Visayan poem since some words are not familiar like "nagmirida". It needs to be familiarized before it will be used for it may create problem once used erroneously. It takes time to think of a word or phrase in composing some Visayan poems; may it be a taboo or formal because all words are subject to be associated with different meaning from one another. Moreover, I found in this study that there are words or phrases used in the selected Visayan poems, which are not familiar to us. The problem here is the language acquisition of the students. This was confirmed by the students during the focus group discussion.

akoa mam kay kinahanglan pa jud siyag more understanding ug balikbalikon ug basa para ma sabtan ang mga words, pag basa nako mam kay na confuse pud (R7, 14)

sa pag basa nako mam honestly murag naa man goy phrase sa akoa mam na kadtung na concept na wala lng mam and nalibug pud jud ko sa deeper meaning sat shirt (R10, L2).

The uncommon words and phrases used in the Visayan poems provided difficulty in understanding as revealed in this study. This drove to the confusion on what really is the exact interpretation of the piece. Thus, vocabulary plays significant role in the scenario.

Rupley and Slough (2010) pointed out that race or ethnicity, language, culture, gender, and socioeconomic status are among the factors that shape the knowledge and experiences that students bring into the classroom. Moreover, many struggling readers may not have as much exposure to literacy events, or lack experience to provide background knowledge. As such, many English language learners (ELL) struggle with reading comprehension. English language learners truly experience the double edged sword in which they are learning a second language, which is the language of instruction (English), and are held accountable for learning of both content and concepts in the English language.

Inappropriateness used of words or diction. Lust, betrayal and pervert are the words which stressed out the most during the conduct of the study. It sounds negative but the author of the Visayan poems meticulously included all of those. The primary purpose is to urge the individual to finish reading the piece. Unexpectedly, it arrived to the point that we, Filipinos are likely to use these words for 
personal expressions. There are the same words used in the poems, which students contested that it is difficult to understand because of its complexity and inappropriateness:

kadtung mouli ra kay mo kayat, masabtan raman iyang mga bisaya mam, tapos nag lisud mig answer mam kay tungod sa mga words kay murag bag o pa siya na encounter pero masabtan raman gamay bisaya mam. $(R 2, L 1)$

The vulgar words and phrases used in this study are also prevalent in an informal writing and creative writing. This made the decision to conclude that formality in writing has a place. It is difficult to associate the concept of the poem through contextualization of the words choice. Thus, the inappropriateness of the words and even phrases used in any literary piece can affect the understanding of the readers.

The language use is undeniably important in writing given that heavy description is much relevant in the writing process. The integration of creative writing opens up the possibility of continuity and discontinuity of one's memory of lived experiences and the nature of identity. In fact, using creative writing to examine the self within the method of heavy description makes a various forms of narrative agency (Mackenzie, 2008). Further, Lenz (2008) insisted that people are sexual creatures. It is not something that is comfortable for everyone to admit, much less exploring through creative writing, but it is something that we need to acknowledge about the characters.

\section{REFERENCES}

[1] Alghadeer, A. (2008). "Digital Landscapes: Rethinking Poetry Interpretation in Multimodal Texts." Journal of Arts and Humanities 3.2 (2014): 87.

[2] Anderson, L.W., \& Krathwohl D.R. (2001). A Taxonomy for Learning, Teaching, and Assessing: A Revision of Bloom's Taxonomy of Educational Objectives. New York: Longman.

[3] Ashtiani, N. S., \& Babaii, E. (2007). Cooperative test construction: The last temptation Educational reform? Studies in Educational Evaluation, 33, 213,228.

[4] Babbie, E. (2001). Qualitative field research. Babbie, ER, The Practice of.

[5] Bassham, G., Irwin, W., Nardone, H., \& Wallace, J. (2012). Critical thinking: A student's introduction (5th ed.). New York, NY: McGraw-Hill Higher Education.

[6] British Columbia's Ministry of Education (2010). Grade 6 Curriculum Package. Retrieved from http://www.bced.gov. bc.ca/irp/curric_grade_packages/gr6curric_req.pdf.

[7] Cottrell, S. (2005). Critical thinking skills: Developing effective analysis and argument. Basingstoke, UK. Palgrave Macmillan.
[8] Crawley, R. L. (2014). Favor; an autoethnography of survival. In R. M. Boylorn \& M. P. Orbe (Eds.), Critical autoethnography; Intersecting cultural identities in everyday life (pp. 222-233). Walnut Creek CA: Left Coast Press.

[9] Creswell, J. W. (1998). Qualitative inquiry and research design: Choosing among five designs.

[10] Curriculum Development Council (2007). New senior secondary curriculum and assessment guide (secondary 4-6): Integrated Science. Retrieved fromhttp://334.edb.hke dcity.net/EN/curriculum.php.

[11] Denzin, N.K. (1978). The Research Act, 2ème Edi., New York: McGraw-Hill.

[12] Dick, W., Carey, L. \& Carey, J. O. (2014). Systematic design of instruction (8th ed.). New York, NY: Pearson.

[13] Ellis, C., Adams, T. E. \& Bochner, A. P. (2011). Autoethnography: an overview. Forum: Qualitative Social Research, 12 (1) Art. 10. Retrieved from http://www.qualitative research.net/index.php/fqs/article/vi ew/1589/3095

[14] Emanovský, P., \& Štěpánková, B. (2012). On Some Experience with an Innovation of Initial Mathematics Teacher Training and its Evaluation. In Proceedings of abstracts of 6th Annual International Conference on Mathematics, Statistics, and Mathematics Education.

[15] Estrecho, F. \& Fernandez, F. (2011). A Comparative Study on the Degree of Knowledge about Sex Between Teenage Males and Teenage Females Age (13-17 Yrs Old). Undergraduate thesis. University of the Philippines Cebu College, Cebu City.

[16] Freud, S. (1912). Recommendations to physicians practising psycho-analysis.

[17] Gabuyo, Y. (2012). Assessment of Learning 1. Textbook and Reviewer 84-86 P. Florante St., Sta Mesa Heights, Quezon City.

[18] Hirsch, E (2007). How to Read a Poem. Retrieved on November 5, 2017 from https://www.poets.org/poetsorg/te $\mathrm{xt} /$ how-read-poem-0

[19] Huang, J. (2008). How accurate are ESL students' holistic writing scores on large-scale assessments? - A generalizability theory approach. Assessing Writing, 13(3), 201-218.

[20] Huang, J. (2009). Factors affecting the assessment of ESL students' writing. International Journal of Applied Educational Studies, 5(1), 1-17.

[21] Huang, J. (2011). Generalizability theory as evidence of concerns about fairness in large-scale ESL writing assessments. TESOL Journal, 2(4), 423-443.

[22] Huang, J. (2012). Using generalizability theory to examine the accuracy and validity of large scale ESL writing. Assessing Writing.

[23] Illouz, E. (2014). Hard-Core Romance "Fifty Shades of Grey," Best-Sellers, and Society. Retrieved on April 10, 2017 from http://www.press.uchicago.edu/ucp/books/book /chicago/H/bo18232225.html 
[24] Ivankova, N. V., Creswell, J. W., \& Stick, S. L. (2006). Using mixed-methods sequential explanatory design: From theory to practice. Field methods, 18(1), 3-20.

[25] Kennedy, R. (2009). The Do's and Dont's of Writing Erotic Fiction. Retrieved on May 11, 2017 from https://litreactor. $\mathrm{com} /$ columns/the-dos-and-donts-of-writing-erotic-fiction.

[26] Khatib, M. (2011). Literature in EFL/ESL classroom. Canadian Center of Science and Education, 4 (1), 201-208.

[27] Kim, K.S. (2003). The role of Similarity and Familiarity in the Metaphor and Simile Preferences (Semyong University).

[28] King, F. J., Goodson, L., \& Rohani, F. (2010). Higher order thinking skills: Definition, teaching strategies, assessment. Publication of the Educational Services Program, now known as the Center for Advancement of Learning and Assessment. Obtido de: www. cala. fsu. edu.

[29] Lam, R. (2014). Can student-generated test materials support learning?. Studies in Educational Evaluation (in press). Retrieved 30, 5, 2014 from http://www.sciencedirect.com/s cience/article/pii/S0191491X1400008X.

[30] Lasch, K. E., Marquis, P., Vigneux, M., Abetz, L., Arnould, B., \& Bayliss, M. (2010). PRO development: Rigorous qualitative research as the crucial foundation. Quality of Life Research, 19(8), 1087-1096. doi: 10.1007/s11136-010 $-9677-6$.

[31] Lenz, S. (2008). The Virgin Page: A Peek at Writing Erotica. Retrieved on May 11, 2017 from http://www.toasted-chees e.com/absolute-blank/08-09/.

[32] Mackenzie, C. (2008). Introduction: practical identity and narrative agency. In C. Mackenzie \& K. Atkins (Eds.), Practical identity and narrative agency (pp. 1-28). New York: Routledge.

[33] Mason, M. (2010, August). Sample size and saturation in $\mathrm{PhD}$ studies using qualitative interviews. In Forum qualitative Sozialforschung/Forum: qualitative social research (Vol. 11, No. 3).

[34] McGlone, M. S, \& Glucksberg, S. (2001). Understanding figurative language: From metaphor to idioms (No. 36). Oxford University Press on Demand.

[35] Ministry of Education (2013). The Malaysian Education Blueprint 2013 - 2025: Preschool to Post Secondary. Putrajaya Malaysia: Author.

[36] Ministry of Education Malaysia (2015). The Malaysian Education Blueprint 2015 - 2025 (Higher Education). Putrajaya Malaysia: Author.

[37] Morse, J.M. (1994). Designing funded qualitative research. In Norman K. Denzin \& Yvonna S. Lincoln (Eds.), Handbook of qualitative research (2nd ed., pp.220-35). Thousand Oaks, CA: Sage.

[38] Murphey, T. (1995). Tests: Learning Through Negotiated Interaction. TESOL Journal, 4, 12-16.

[39] National Council of Teacher of English (2014). How Standardized Tests Shape - and Limit - Student Learning. Retrieved on April 6, 2017 from http://www.ncte.org/librar y/NCTEFiles/Resources/Journals/CC/0242-nov2014/CC02 42PolicyStandardized.pdf
[40] Nelson, H. (2013). Testing more, teaching less: What America's obsession with student testing costs in money and lost instructional time. New York: American Federation of Teachers.

[41] Onwuegbuzie, A. J., \& Collins, K. M. (2007). A Typology of Mixed Methods Sampling Designs in Social Science Research. The Qualitative Report, 12 (2), 281-316. Retrieved from http://nsuworks.nova.edu/tqr/vol12/iss2/9.

[42] Onwuegbuzie, A. J., Leech, N. L., \& Collins, K. M. T. (2010). Innovative data collection strategies in qualitative research. The Qualitative Report, 15(3), 696-726. Retrieved from http://www.nova.edu/ssss/QR/QR15-3/onwuegbuzie. pdf.

[43] Paul, S. (2015). Metaphor and Similes in English: Langston Hughes Teaches Us the Difference. www.skypeenglishclas ses.com/skype-english-blog/metaphor-and-simile-in-englis h-langston-hughes-teaches-us-difference.

[44] Popham, W. J. (2008). Classroom assessment: What teachers need to know (5th Ed.). Pearson Education, Inc.

[45] Popham, W. J. (2011). Classroom assessment: What teachers need to know (6th Ed.). Pearson Education, Inc.

[46] Remote, D. (2017). Sex from ancient times to now. From The Philippine Star Retrieved on April 4, 2017 from http://www.philstar.com/opinion/2017/04/01/1686535/sexancient-times-now

[47] Richards, J. C. \& Schmidt, R. (2002). Longman dictionary of language teaching and applied linguistics. Third ed. London: Longman.

[48] Rupley, W. H., \& Slough, S. (2010). Building Prior Knowledge and Vocabulary in Science in the Intermediate Grades: Creating Hooks for Learning. Literacy Research and Instruction, 49(2), 99-112. doi: 10.1080/1938807090 2780472

[49] Seif, A.A.A.Q.A. (2010). Evaluating the Higher Order Thinking Skills in Reading Exercises of English for Palestine Grade 8 (Doctoral dissertation, The Islamic University-Gaza).

[50] Septiana, S. (2013). A Critical Discourse Analysis of Figurative Language in Pakistani English Newspapers', International Journal of Linguistics, Vol. 6, p. 212.

[51] Shamisa, S. (2004). Rhetoric 2. Tehran: Payamnoor Publication.

[52] Siswantoro, D, Nik Ahmad, N. \& N., Sulaiman, M., (2002). Corporate social disclosure practices in Malaysia: A content analysis. Unpublished Working Paper. International Islamic University Malaysia. Nunnally JC (1988). Psychometric Theory, McGraw-Hill: Englewood Cliffs, New Jersey.

[53] Struthers, J. (2014). Analytic autoethnography: One story of the method. In J. Huisman \& M. Tight (Eds.), Theory and method in higher education research II (International perspectives on higher education research (Vol. 10, pp.183202), Emerald Group Publishing Limited.

[54] Sultan, W.H., Woods, P.C. and Koo, A.C. (2011). A constructivist approach for digital learning: Malaysian schools case study. Educational Technology \& Society, 14(4), pp. 149-163. 
[55] Sylvan, E. (2008). Literature for Composition: Reading and Writing Arguments about Essays, Fiction, Poetry, and Drama. Recording for the Blind \& Dyslexic.

[56] Vandermensbrugghe, J. (2004). The unbearable vagueness of critical thinking in the context of Anglo Saxonisation of education. International Education Journal, 5(3). pp. 417422 .

[57] Weiss, L. (2006). Figurative Language in Biblical Prose Narrative Metaphor. (Brill Leiden; Boston) 5.

[58] Wiggan, G. (2014). Student achievement for whom? Highperforming and still "playing the game," the meaning of school achievement among high achieving African American students. Urban Review, 46, 47-492.

[59] William, D. (2011). What is assessment for learning? Studies in Educational Evaluation. 37, 3-14.

[60] Zarghami, Z. \& Baleghizadeh, B. (2014). Student-Generated Tests and Their Impact on EFL Students' Learning of Grammar. Journal of Theory and Practice in Education ISSN: 1304-9496 Retrieved on April 8, 2017 from http://dergipark.gov.tr/download/article-file/63412.

[61] Zohrabi, M. (2013). Mixed Method Research: Instruments, Validity, Reliability and Reporting Findings. ISSN 1799-2591 Theory and Practice in Language Studies, Vol. 3, No. 2, pp. 254-262, February 2013 (C) 2013 ACADEMY PUBLISHER Manufactured in Finland. doi: 10.4304/tpls.3 .2.254-262. 